\title{
Peran Lembaga Penjamin Simpanan Dalam Pengelolaan Sistem Stabilitas Keuangan Indonesia
}

\author{
Rudy Susanto ${ }^{1}$, Zainal Arifin H. Masri ${ }^{2}$ \\ Universitas Indraprasta PGRI, Jakarta ${ }^{1,2}$
}

\begin{abstract}
The purpose of the study is to find out: (1) The purpose of financial system stability; (2) Indicators used to declare financial system instability; (3) The work mechanism of the financial system stability committee; (4) Role and function of the IDIC in participating in managing financial system stability; (5) The maximum value of deposits guaranteed by LPS; (6) Many banks are included in the LPS oversight and actions taken by the LPS. This research uses the case study method with qualitative descriptive analysis. The results of the study: (1) There is no standard definition of financial system stability that is accepted by the international world, but at least a stable, healthy and strong financial system is able to allocate sources of funds, perform intermediary functions, carry out payments, spread risk well, prevent and resistant to disruption to the real sector and financial system; (2) There are 2 indicators, namely prudential microeconomic and macroeconomic; (3) KSSK has the duty to oversee economic indicators so that financial system stability is achieved; (4) DIC functions to guarantee customer deposits and handle failed banks; (5) Deposit guaranteed by LPS is a maximum of Rp 2 billion; (6) In 2019 there were 100 banks handled by LPS. An unstable financial system will affect the stability of the overall economic system. LPS has succeeded in arousing public trust to save.
\end{abstract}

Keywords: Financial System Stability, Financial System Crisis, KSSK, LPS..

\section{Pendahuluan}

Sistem keuangan adalah bagian integral dari sistem perekonomian yang berisi kumpulan institusi, pasar, peraturan-peraturan, ketentuan perundangan, dan teknikteknik surat berharga diperdagangkan, tingkat bunga yang ditetapkan dan jasa-jasa keuangan yang dihasilkan dan ditawarkan ke berbagai penjuru dunia (Peter S. Rose, 2000). Sistem keuangan mempunyai tugas utama dalam perekonomian, yaitu memindahkan dana dari penabung (pihak yang surplus dana) kepada peminjam yang membutuhkan dana (pihak yang defisit dana) untuk membeli barang dan jasa 
serta untuk investasi.

Tatanan perekonomian suatu negara terdiri dari sistem perbankan, sistem lembaga keuangan bukan bank dan otoritas keuangan. Berdasarkan UndangUndang No. 9 Tahun 2016 tentang Pencegahan dan Penanganan Krisis Sistem Keuangan, otoritas keuangan berada pada Komite Stabilitas Sistem Keuangan (KSSK). KSSK mempunyai peran untuk menyelenggarakan pencegahan dan penanganan krisis sistem keuangan bagi kepentingan negara di bidang perekonomian. Anggota KSSK terdiri dari Menteri Keuangan sebagai Koordinator, Gubernur Bank Indonesia, Ketua Dewan Komisioner Otoritas Jasa Keuangan (OJK) dan Ketua Dewan Komisioner Lembaga Penjamin Simpanan (LPS).

LPS merupakan suatu lembaga yang menyelenggarakan penjaminan terhadap simpanan nasabah bank untuk menjaga dan memelihara stabilitas sistem perbankan. Dengan sistem perbankan yang stabil dan kokoh, maka akan terbentuk perekonomian yang kuat, kokoh dan stabil. Sebaliknya jika sistem keuangan tidak stabil akan menyebabkan kemampuan sektor perusahaan dan rumah tangga untuk memenuhi kebutuhannya akan barang dan jasa serta untuk melakukan investasi berkurang, tingkat bunga kredit sangat tinggi, dana yang dapat dipinjamkan jumlah yang terbatas, total pengeluaran berkurang, pengangguran meningkat dan pertumbuhan ekonomi terganggu dan mengalami penurunan. Oleh karena itu LPS sangat diperlukan untuk pengelolaan stabilitas sistem keuangan.

Berdasarkan uraian latar belakang tersebut di atas, maka rumusan masalah yang terdapat pada penelitian ini, yaitu : 1) Apa yang dimaksud stabilitas sistem keuangan ? ; 2) Apa indikator yang digunakan untuk menyatakan ketidakstabilan sistem keuangan ? ; 3) Bagaimana mekanisme kerja komite stabilitas sistem keuangan ? ; 4) Apa peran dan fungsi LPS dalam keikutsertaannya mengelola stabilitas sistem keuangan ? ; 5) Berapa besar nilai maksimum simpanan yang dijamin oleh LPS ? ; 6) Berapa banyak bank yang berada dalam pengawasan LPS dan Tindakan apa yang diambil oleh LPS ?

Penelitian ini bertujuan untuk mengetahui : 1) Maksud dari stabilitas sistem keuangan ;2) Indikator yang digunakan untuk menetapkan sistem keuangan berada dalam kondisi tidak stabil ; 3) Mekanisme kerja KSSK dalam pengelolaan stabilitas 
sistem keuangan ; 4) Peran dan fungsi LPS dalam keikutsertaannya mengelola stabilitas sistem keuangan ; 5) Nilai maksimum simpanan yang dijamin oleh LPS ; 6) Jumlah bank yang berada dalam pengawasan LPS dan tindakan yang diambil oleh LPS.

\section{Tinjauan Pustaka}

\section{Sistem Keuangan}

Sistem keuangan merupakan bagian tak terpisahkan dari sistem perekonomian secara keseluruhan. Sistem keuangan adalah bagian integral dari sistem perekonomian yang berisi kumpulan institusi, pasar, peraturan-peraturan, ketentuan perundangan, dan teknik-teknik surat berharga diperdagangkan, tingkat bunga yang ditetapkan dan jasa-jasa keuangan yang dihasilkan dan ditawarkan ke berbagai penjuru dunia (Peter S. Rose, 2000).

Sistem keuangan adalah sistem yang terdiri atas lembaga jasa keuangan, pasar keuangan, dan infrastruktur keuangan, termasuk sistem pembayaran, yang berinteraksi dalam memfasilitasi pengumpulan dana masyarakat dan pengalokasiannya untuk mendukung aktifitas perekonomian nasional (UndangUndang No. 9 Tahun 2016 Pasal 1 Ayat 1).

Sistem keuangan terdiri dari sistem perbankan, sistem lembaga keuangan non bank dan otoritas keuangan. Sitem perbankan berdasarkan fungsinya terdiri dari Bank Sentral yaitu Bank Indonesia, Bank Umum dan Bank Perkreditan Rakyat (BPR). Bank umum maupun BPR dapat menjalankan kegiatannya secara konvensional maupun secara syariah. Sistem lembaga keuangan non bank terdiri dari Asuransi, Leasing, Modal Ventura, Dana Pensiun, Perusahaan Investasi, Bursa Efek, Reksa Dana, dan Pegadaian. Otoritas keuangan dikelola oleh Komite Stabilitas Sistem Keuangan (KSSK) yang anggotanya terdiri dari Menteri Keuangan, Gubernur Bank Indonesia, Dewan Komisioner Otoritas Jasa Keuangan (OJK) dan Dewan Komisioner Lembaga Penjamin Simpanan, dimana Menteri Keuangan bertindak sebagai koordinatornya.

Tugas utama semua sistem keuangan adalah memindahkan dana dari pemilik dana (penabung) kepada pihak yang membutuhkan dana (peminjam) untuk 
membeli barang dan jasa (konsumsi) dan untuk membeli barang-barang modal/investasi (Siamat, 2005).

Dewasa ini sistem keuangan dalam sistem perekonomian memiliki beberapa fungsi pokok, yaitu : 1) Fungsi tabungan/saving function (sistem keuangan yang menyediakan instrumen-instrumen keuangan, seperti: saham, obligasi dan surat berharga lainnya dan menjanjikan pendapatan dengan resiko kecil serta mekanisme transaksinya) ; 2) Fungsi kekayaan/wealth fungsion (membeli instrumen keuangan yang dihasilkan sistem keuangan untuk menyimpan kekayaan) ; 3) Fungsi likuiditas/liquidity function (pemilik dana yang menyimpan kekayaannya dalam instrumen keuangan apabila memerlukan dana segar/uang tunai, maka instrumen keuangannya dengan segera dapat diubah/dicairkan dalam bentuk uang tunai dengan resiko rendah) ; 4) Fungsi kredit/credit function (pasar keuangan dalam sistem keuangan yang menyediakan fasilitas kredit untuk membiayai konsumsi dan investasi) ; 5) Fungsi pembayaran/payment function (pembayaran atas transaksi barang dan jasa dapat menggunakan instrumen keuangan yang disediakan sistem keuangan, seperti: cek, giro, kartu kredit, kartu debit, transfer elektronik, phone banking, electronic banking dan sebagainya) ; 6) Fungsi resiko/risk function (sistem keuangan juga memberikan perlindungan atas harta, jiwa, kesehatan, dan resiko kerugian atas semua kegiatan usaha, seperti asuransi) ; 7) Fungsi kebijakan/policy function (otoritas keuangan yang merupakan bagian dari sistem keuangan dapat membuat kebijakan dengan membuat peraturan untuk menstabilkan sistem keuangan dan perekonomian keseluruhan) (Peter S. Rose, 2000).

Pertumbuhan dan perkembangan ekonomi membutuhkan perekonomian yang stabil yang harus didukung oleh stabilitas sistem keuangan. Stabilitas sistem keuangan adalah kondisi sistem keuangan yang berfungsi efektif dan efisien serta mampu bertahan dari gejolak yang bersumber dari dalam negeri dan luar negeri (UU No. 9/2016 pasal 1 ayat 2). Stabilitas sistem keuangan merupakan tanggung jawab dari KSSK, dimana KSSK melakukan upaya-upaya pencegahan dan penanganan krisis sistem keuangan untuk melaksanakan kepentingan dan ketahanan negara di bidang perekonomian.

Krisis keuangan merupakan kondisi sistem keuangan yang gagal menjalankan 
fungsi dan perannya secara efektif dan efisien, yang ditunjukkan dengan memburuknya berbagai indikator ekonomi dan keuangan (UU No. 9/2016 pasal 2).

Dasar pencegahan dan penanganan krisis sistem keuangan diselenggarakan dengan memperhatikan kepentingan nasional, kemanfaatan, keadilan, keterpaduan, efektifitas, efisiensi dan kepastian hukum. Pencegahan dan penanganan krisis sistem keungan meliputi : Koordinasi pemantauan dan pemeliharaan stabilitas sistem keuangan ; Penanganan krisis sistem keuangan ; Penanganan permasalahan bank sistemik, baik dalam kondisi sistem keuangan stabil atau normal maupun sistem keuangan dalam kondisi krisis.

Keputusan KSSK untuk menyatakan sistem keuangan berada dalam kondisi krisis dengan memperhatikan berbagai aspek perekonomian negara. Seluruh aspek perekonomian negara tersebut, antara lain: Fiskal ; Moneter ; Makroprudensial dan mikroprudensial jasa keuangan ; Pasar keuangan ; Infrastruktur keuangan, termasuk sistem pembayaran dan penjaminan simpanan ; Resolusi bank.

\section{Lembaga Penjamin Simpanan (LPS)}

LPS adalah badan hukum yang dibentuk dan didirikan berdasarkan UndangUndang No. 24 Tahun 2004 tentang lembaga penjamin simpanan. LPS dibentuk untuk melaksanakan program panjaminan simpanan nasabah bank dalam rangka mendukung sistem perbankan yang sehat dan stabil. Sistem perbankan yang sehat dan stabil sangat diperlukan untuk mewujudkan perekonomian nasional yang stabil, sehat, kuat dan tangguh. LPS dalam menjalankan tugas dan wewenangnya bersifat independen, bebas dari campur tangan pemerintah/kekuasaan, transparan, terbuka bagi masyarakat banyak, dan akuntabel, dapat dipercaya dan diandalkan. LPS mempunyai fungsi (UU No. 24/2004 pasal 4): Menjamin simpanan nasabah penyimpan ; Turut aktif dalam memelihara stabilitas sistem perbankan (yang merupakan bagian dari sistem keuangan) sesuai dengan kewenangannya. Misalnya penyelesaian atau penanganan bank gagal.

Tugas LPS dalam menjalankan fungsinya (UU. No. 24/2004 pasal 5 ayat 1 dan 2) : 1) Merumuskan dan menetapkan kebijakan pelaksanaan penjaminan simpanan ; 2) Melaksanakan penjaminan simpanan ; 3) Merumuskan dan 
menetapkan kebijakan dalam rangka turut aktif memelihara stabilitas sistem perbankan ; 4) Merumuskan, menetapkan, dan melaksanakan kebijakan penyelesaian bank gagal (bank resolution) yang tidak berdampak sistemik ; 5) Melaksanakan penanganan bank gagal yang berdampak sistemik.

LPS memiliki beberapa kewenangan di dalam menjalankan tugasnya (UU No. 24/2004 pasal 6 ayat 1 dan 2, dan pasal 7), yaitu : 1) Menetapkan dan memungut premi penjaminan ; 2) Menetapkan dan memungut kontribusi pada saat bank pertama kali menjadi peserta penjaminan ; 3) Melakukan pengelolaan kekayaan dan kewajiban LPS ; 4) Mendapatkan data simpanan nasabah, data kesehatan bank, laporan keuangan bank, laporan hasil pemeriksaan bank, sepanjang tidak melanggar kerahasiaan bank ; 5) Melakukan rekonsialisasi, verifikasi, dan/atau konfirmasi atas data ; 6) Menetapkan syarat, tatacara, dan ketentuan pembayaran klaim ; 7) Menunjuk, menguasakan, dan/atau menugaskan pihak lain untuk bertindak bagi kepentingan dan/atau atas nama LPS, guna melaksanakan sebagian tugas tertentu ; 8) Melakukan penyuluhan kepada bank dan masyarakat tentang penjaminan simpanan ; 9) Menjatuhkan sanksi administratif ; 10) Mengambil alih dan menjalankan segala hak dan wewenang pemegang saham, termasuk hak dan wewenang RUPS ; 11) Menguasai dan mengelola aset dan kewajiban bank gagal yang diselamatkan ; 12) Meninjau ulang, membatalkan, mengakhiri, dan/atau mengubah setiap kontrak yang mengikat bank gagal yang diselamatkan dengan pihak ketiga yang merugikan bank ; 13) Menjual dan/atau mengalihkan aset bank tanpa persetujuan debitur dan/atau kewajiban bank tanpa persetujuan kreditur ; 14) Dapat meminta data, informasi dan/atau dokumen kepada pihak lain.

LPS memberikan perlindungan terhadap dua risiko yakni irrational run dan systemic risk. Dalam menjalankan kegiatan usaha dalam bentuk pemberian kredit, bank biasanya hanya menyisakan sebagian kecil dari simpanan yang diterimanya untuk berjaga-jaga apabila ada penarikan dana oleh nasabah. Sementar bagian terbesar dari simpanan yang ada dialokasikan untuk pemberian kredit. Keadaan ini menyebabkan perbankan tidak dapat memenuhi permintaan dalam jumlah besar dengan segera atas simpanan nasabah yang dikelolanya, bila terjadi penarikan secara tiba-tiba dan dalam jumlah besar. Keterbatasan dalam penyediaan dana cash 
ini adalah karena bank tidak dapat menarik segera pinjaman yang telah disalurkannya. Bila bank tidak dapat memenuhi permintaan penarikan simpanan oleh nasabahnya, nasabah biasanya menjadi panik dan akan menutup rekeningnya pada bank dimaksud, sekalipun bank tersebut sebenarnya sehat. Sedangkan risiko sistemik terjadi apabila kebangkrutan satu bank berakibat buruk terhadap bank lain, sehingga menghancurkan segmen terbesar dari sistem perbankan. (Alan D. Moririson, "Systemic Risk and the 'too-big-to-fail' Problem”, Oxford Review of Economic Policy, Volume 27, Number 3, 2011., http://www.macroeconomics.tuberlin.de diakses pada tanggal 24 Oktober 2019).

\section{Metode Penelitian}

Metode penelitian yang digunakan dalam penelitian ini adalah penelitian kualitatif deskriptip dengan pengambilan sampel sumber data secara purposive dan snowball. Analisis data dilakukan sejak sebelum memasuki lapangan (berdasarkan data hasil studi pendahuluan atau data sekunder), selama di lapangan dan setelah selesai dilapangan (Reduksi data/Data Reduction; Menyajikan data/Display Data; Membuat kesimpulan dan memverifikasi).

\section{Hasil Dan Pembahasan}

\section{Stabilitas Sistem Keuangan}

Sistem keuangan merupakan bagian dari sistem perekonomian. Sistem keuangan yang tidak stabil akan membuat sistem perekonomian tidak stabil secara keseluruhan. Stabilitas Sistem Keuangan (SSK) belum atau tidak memiliki definisi baku yang diterima secara global oleh dunia internasional. Bank Indonesia memberikan beberapa definisi dari stabilitas sistem keuangan, (www.bi.go.id, diakses 25 Desember 2019) antara lain : 1) Sistem keuangan yang stabil mampu mengalokasikan sumber dana dan menyerap kejutan (shock) yang terjadi sehingga dapat mencegah gangguan terhadap kegiatan sektor riil dan sistem keuangan ; 2) Sistem keuangan yang stabil adalah sistem keuangan yang kuat dan tahan terhadap berbagai gangguan ekonomi sehingga tetap mampu melakukan fungsi intermediasi, melaksanakan pembayaran dan menyebar risiko secara baik ; 3) Stabilitas sistem 
keuangan adalah suatu kondisi dimana mekanisme ekonomi dalam penetapan harga, alokasi dana dan pengelolaan risiko berfungsi secara baik dan mendukung pertumbuhan ekonomi.

Globalisasi sektor finansial yang semakin mendunia yang didukung oleh perkembangan teknologi 4.0 dan inovasi produk keuangan yang beragam menyebabkan sistem keuangan menjadi semakin terintegrasi pada semua negara tanpa jeda waktu dan mengatasi batas wilayah. Berbagai perkembangan tersebut selain dapat mengakibatkan sumber-sumber pemicu ketidakstabilan sistem keuangan meningkat dan semakin beragam, uga dapat mengakibatkan semakin sulitnya mengatasi ketidakstabilan tersebut.

Mengidentifikasi sumber ketidakstabilan sistem keuangan menjadi sangat penting untuk mengetahui potensi risiko yang akan timbul serta akan mempengaruhi kondisi sistem keuangan mendatang. Atas dasar hasil identifikasi tersebut selanjutnya dilakukan analisis sampai seberapa jauh risiko berpotensi menjadi semakin membahayakan, meluas dan bersifat sistemik sehingga mampu melumpuhkan perekonomian.

Krisis moneter tahun 1998 membuktikan bahwa stabilitas sistem keuangan merupakan aspek yang sangat penting dalam membentuk dan menjaga perekonomian yang berkelanjutan. Sistem keuangan yang tidak stabil cenderung rentan terhadap berbagai gejolak sehingga mengganggu perputaran roda perekonomian. Penanganan sistem keuangan yang tidak stabil memerlukan biaya yang sangat tinggi untuk upaya penyelamatannya dan waktu yang lama untuk menumbuhkembangkan kembali kepercayaan masyarakat terhadap sistem keuangan. Atas dasar kondisi tersebut, upaya untuk menghindari atau mengurangi risiko kemungkinan terjadinya ketidakstabilan sistem keuangan sangatlah diperlukan, terutama untuk menghindari kerugian yang begitu besar lagi.

Sistem keuangan yang tidak stabil dapat mengakibatkan timbulnya beberapa kondisi yang tidak menguntungkan seperti : 1) Transmisi kebijakan moneter tidak berfungsi secara normal sehingga kebijakan moneter menjadi tidak efektif ;2) Fungsi intermediasi tidak dapat berjalan sebagaimana mestinya akibat alokasi dana yang tidak tepat sehingga menghambat pertumbuhan ekonomi ; 3) 
Ketidakpercayaan publik terhadap sistem keuangan yang umumnya akan diikuti dengan perilaku panik para investor untuk menarik dananya sehingga mendorong terjadinya kesulitan likuiditas ; 4) Sangat tingginya biaya penyelamatan terhadap sistem keuangan apabila terjadi krisis yang bersifat sistemik.

Ada dua indikator utama yang menjadi penyebab instabilitas sistem keuangan, yakni indikator microprudential dan indikator makroekonomi. Kedua indikator tersebut saling melengkapi sebagai aksi dan reaksi dalam sistem keuangan dan ekonomi Pengawasan indikator microprudential dilakukan untuk mengetahui potensi risiko likuiditas, risiko pasar, risiko kredit dan rentabilitas institusi keuangan, yang dimaksudkan untuk mengukur ketahanan sistem keuangan.

Pengawasan indikator makroekonomi untuk mengetahui kondisi makroekonomi domestik maupun internasional yang berdampak signifikan terhadap stabilitas keuangan. Berdasarkan hasil pengawasan tersebut, selanjutnya dilakukan analisis guna memprediksi kondisi stabilitas sistem keuangan.

Tabel 1. Indikator Pengukuran Stabilitas Sistem Keuangan

\begin{tabular}{|l|l|}
\hline \multicolumn{1}{|c|}{ Indikator microprudential (Agregat) } & \multicolumn{1}{|c|}{ Indikator makroekonomi } \\
\hline & Pertumbuhan ekonomi \\
Cakupan modal & Tingkat pertumbuhan agregat \\
Rasio modal agregat & Sektor ekonomi yang jatuh \\
alitas Aset & BOP \\
agi Kreditur & Defisit neraca berjalan \\
Konsentrasi kredit secara sektoral & Kecukupan cadangan devisa \\
Pinjaman dalam mata uang asing & Pinjaman luar negeri (termasuk struktur jangka \\
Pinjaman terhadap pihak terkait, kredit macet (NPL) & waktu) \\
dan pencadangannya & Term of trade \\
- Bagi Debitur & Komposisi dan jangka waktu aliran modal \\
DER (rasio hutang thd modal), laba perusahaan & Inflasi \\
Manajemen Sistem Keuangan yang Sehat & Volatilitas inflasi \\
Pertumbuhan jumlah lembaga keuangan, dan lain-lain & Suku Bunga dan Nilai Tukar \\
Pendapatan dan Keuntungan & Volatilitas suku bunga dan nilai tukar \\
ROA, ROE, dan rasio beban terhadap pendapatan & Tingkat suku bunga domestik \\
Likuiditas & Stabilitas nilai tukar yang berkelanjutan \\
Kredit bank sentral kpd Lemb.Keu, LDR, struktur & Jaminan nilai tukar \\
jangka waktu aset dan kewajiban & Efek menular \\
Sensitivitas terhadap risiko pasar & Trade spillover \\
Risiko nilai tukar, suku bunga dan harga saham & Korelasi pasar keuangan \\
Indikator berbasis pasar & Faktor-faktor lain \\
Harga pasar instrumen keuangan, peringkat kredit, & Investasi dan pemberian pinjaman yang terarah \\
sovereign yield spread, dll. & Dana pemerintah pada sistem perbankan \\
Sumber Bank Indonesia & Hutang jatuh tempo \\
\hline
\end{tabular}

Sumber : Bank Indonesia 
Undang-undang No. 9 Tahun 2016 pasal 4 mewajibkan dibentuknya Komite Stabilitas Sistem Keuangan (KSSK). KSSK menyelenggarakan pencegahan dan penanganan Krisis Sistem Keuangan untuk melaksanakan kepentingan dan ketahanan negara di bidang perekonomian. Anggota KSSK terdiri dari :

1. Menteri Keuangan sebagai koordinator merangkap anggota dengan hak suara;

2. Gubernur Bank Indonesia sebagai anggota dengan hak suara;

3. Ketua Dewan Komisioner Otoritas Jasa Keuangan sebagai anggota dengan hak suara; dan

4. Ketua Dewan Komisioner Lembaga Penjamin Simpanan sebagai anggota tanpa hak suara.

\section{Tugas}

- Melakukan koordinasi dalam rangka pemantauan dan pemeliharaan Stabilitas Sistem Keuangan

- Melakukan penanganan Krisis Sistem Keuangan

- Melakukan penanganan permasalahan Bank Sistemik, baik dalam kondisi Stabilitas Sistem Keuangan normal maupun kondisi Krisis Sistem Keuangan

\section{Wewenang}

- Menetapkan keputusan mengenai tata kelola Komite Stabilitas Sistem Keuangan dan sekretariat Komite Stabilitas Sistem Keuangan

- Membentuk gugus tugas atau kelompok kerja untuk membantu pelaksanaan tugas Komite Stabilitas Sistem Keuangan

- Menetapkan kriteria dan indikator untuk penilaian kondisi Stabilitas Sistem Keuangan

- Melakukan penilaian terhadap kondisi Stabilitas Sistem Keuangan berdasarkan masukan dari setiap anggota Komite Stabilitas Sistem Keuangan, beserta data dan informasi pendukungnya

- Menetapkan langkah koordinasi untuk mencegah Krisis Sistem Keuangan dengan mempertimbangkan rekomendasi dari setiap anggota Komite Stabilitas Sistem Keuangan 
- Merekomendasikan kepada Presiden untuk memutuskan perubahan status Stabilitas Sistem Keuangan, dari kondisi normal menjadi kondisi Krisis Sistem Keuangan atau dari kondisi Krisis Sistem Keuangan menjadi kondisi normal

- Merekomendasikan kepada Presiden untuk memutuskan langkah penanganan Krisis Sistem Keuangan

- Menyerahkan penanganan permasalahan solvabilitas Bank Sistemik kepada Lembaga Penjamin Simpanan

- Menetapkan langkah yang harus dilakukan oleh anggota Komite Stabilitas Sistem Keuangan untuk mendukung pelaksanaan penanganan permasalahan Bank Sistemik oleh Lembaga Penjamin Simpanan

- Menetapkan keputusan pembelian oleh Bank Indonesia atas Surat Berharga Negara yang dimiliki Lembaga Penjamin Simpanan untuk penanganan Bank

- Merekomendasikan kepada Presiden untuk memutuskan penyelenggaraan dan pengakhiran Program Restrukturisasi Perbankan.

\section{Peran dan Fungsi LPS}

Program penjaminan pemerintah (blanket guarantee) telah berhasil mengembalikan kepercayaan masyarakat terhadap sistem perbankan. Namun, kebijakan tersebut tersebut meningkatkan beban anggaran negara dan berpotensi menimbulkan moral hazard oleh pihak pengelola bank dan nasabah bank. Dalam rangka mengurangi dampak negatif dari program penjaminan pemerintah tersebut, telah didirikan Lembaga Penjamin Simpanan (LPS). Sesuai dengan UndangUndang No. 24 tahun 2004 tentang Lembaga Penjamin Simpanan (LPS) pada tanggal 22 September 2004, LPS memiliki dua fungsi yaitu menjamin simpanan nasabah bank dan melakukan penyelesaian atau penanganan bank yang tidak berhasil disehatkan atau bank gagal.

Penjaminan simpanan nasabah bank yang dilakukan LPS bersifat terbatas untuk mengurangi beban anggaran negara dan meminimalkan moral hazard. Namun demikian, tetap dijaga kepentingan nasabah secara optimal. Setiap bank yang beroperasi di Indonesia baik Bank Umum (bank konvensional dan bank syariah) maupun Bank Perkreditan Rakyat (BPR) diwajibkan untuk menjadi 
peserta penjaminan. Skim penjaminan LPS telah dimulai secara penuh pada tanggal 22 Maret 2007. Adapun jenis simpanan di bank yang dijamin meliputi :

1. Simpanan yang dijamin meliputi giro, deposito, sertifikat deposito, tabungan dan atau bentuk lain yang dipersamakan dengan itu.

2. Simpanan nasabah bank berdasarkan prinsip syariah yang dijamin meliputi:

a. Giro berdasarkan prinsip wadiah

b. Giro berdasarkan prinsip mudharabah

c. Tabungan berdasarkan prinsip wadiah

d. Tabungan berdasarkan prinsip mudharabah muthlaqah atau prinsip mudharabah muqayyadah yang resikonya ditanggung oleh bank

e. Deposito berdasarkan prinsip mudharabah muthlaqah atau prinsip mudharabah muqayyadah yang resikonya ditanggung oleh bank dan/atau

f. Simpanan berdasarkan prinsip syariah lainnya yang ditetapkan oleh LPS setelah mendapat pertimbangan LPP

3. Simpanan yang dijamin mencakup pula simpanan yang berasal dari bank lain.

4. Nilai simpanan yang dijamin LPS mencakup saldo pada tanggal pencabutan izin usaha bank. Saldo tersebut berupa :

a. Pokok ditambah bagi hasil yang telah menjadi hak nasabah, untuk simpanan yang memiliki komponen bagi hasil yang timbul dari transaksi dengan prinsip syariah.

b. Pokok ditambah bunga yang telah menjadi hak nasabah, untuk simpanan yang memiliki komponen bunga

c. Nilai sekarang per tanggal pencabutan izin usaha dengan menggunakan tingkat diskonto yang tercatat pada bilyet, untuk simpanan yang memiliki komponen diskonto.

5. Saldo yang dijamin untuk setiap nasabah pada satu bank adalah hasil penjumlahan saldo seluruh rekening simpanan nasabah pada bank tersebut, baik rekening tunggal maupun rekening gabungan. 
6. Untuk rekening gabungan saldo rekening yang diperhitungkan bagi satu nasabah adalah saldo rekening gabungan tersebut yang dibagi secara prorate dengan jumlah pemilik rekening.

7. Dalam hal nasabah memiliki rekening tunggal dan rekening gabungan, saldo rekening yang terlebih dahulu diperhitungkan adalah saldo rekening tunggal.

8. Dalam hal nasabah memiliki rekening yang dinyatakan secara tertulis diperuntukkan bagi kepentingan pihak lain, maka saldo rekening tersebut diperhitungkan sebagai saldo rekening pihak lain tersebut.

9. Sejak 13 Oktober 2008 saldo yang dijamin untuk setiap nasabah pada satu bank adalah paling banyak sebesar Rp 2 Milyar.

Apabila terdapat bank yang mengalami kesulitan keuangan dan gagal disehatkan kembali sehingga harus dicabut izin usahanya, LPS akan membayar simpanan setiap nasabah bank tersebut sampai jumlah tertentu, sebagaimana ditetapkan. Adapun simpanan nasabah yang tidak dijamin akan diselesaikan melalui proses likuidasi bank. Dengan adanya penjaminan simpanan nasabah bank oleh LPS, diharapkan kepercayaan masyarakat terhadap industri perbankan dapat tetap terpelihara. Tahun 2019 ada 100 bank yang ditangani LPS

\section{Kesimpulan}

Berdasarkan hasil yang diperoleh dan pembahasan yang dilakukan maka dapat diambil suatu kesimpulan sebagai berikut :

1. Sistem keuangan memegang peranan yang sangat penting dalam perekonomian. Sistem keuangan yang tidak stabil dapat menyebabkan perekonomian terganggau. Pemulihan sistem perekonomian yang tidak stabil membutuhkan biaya yang sangat tinggi dan waktu yang lama untuk memulihkan kepercayaan masyarakat pada sistem keuangan dan system perbankan.

2. LPS memiliki dua fungsi yaitu menjamin simpanan nasabah bank dan melakukan penyelesaian atau penanganan bank yang tidak berhasil disehatkan atau bank gagal. 
3. LPS berhasil menumbuhkan dan membangkitkan kembali kepercayaan masyarakat terhadap sistem keuangan dan sistem perbankan

Berdasarkan hasil pnelitian dan pembahasan serta kesimpulan, maka peniliti memberikan saran, bahwa untuk mengawasi stabilitas sistem keuangan, pemerintah harus membentuk Komite Stabilitas Sistem Keuangan (KSSK) yang beranggotakan Menteri Keuangan, Gubernur BI, Ketua Dewan Komisioner OJK dan Ketua Dewan Komisioner LPS. Dimana masing-masing lembaga menjalankan fungsinya masingmasing dengan baik. Pemerintah melalui Menteri Keuangan melakukan kebijakan fiskal, BI melakukan kebijakan moneter, OJK melakukan pengawasan terhadap lembaga keuangan bank dan lembaga keuangan bukan bank sedangkan LPS melakukan fungsi penjaminan dan penanganan bank gagal.

\section{DAFTAR PUSTAKA}

Bogdan. Robert dan Steven J.Taylor. 1992. Pengantar Metode Penelitian Kualitatif. Penerjemah Arif Furhan, Surabaya: Usaha Nasional.

Creswell, John W., 1997. Qualitatve Inquiry and Research Design: Choosing Among Five Traditions, London: SAGE Publication

Danim, Sudarman. 2002. Menjadi Peneliti Kualitatif, Bandung: Pustaka Setia.

Lincoln, Yvonna dan Egon G. Guba. 1985. Naturalitic Inquiry.(London:Sage Publication).

Morrison. Alan D. "Systemic Risk and the 'too-big-to-fail' Problem”, Oxford Review of Economic Policy, Volume 27, Number 3 Tahun 2011.

Miles, Matthew B, dan A.Michael Huberman. 1995. Qualitative data Analysis Beverly Hills : SAGE Publication, Inc.

Rose, Peter S. 2000. Money and Capital Markets : Financial Institutions Instrumen in the Global Market Palace, 7 edition, Taxas A and $\mathrm{M}$

Siamat, Dahlan. 2005. Manajemen Lembaga Keuangan : Kebijakan Moneter dan Perbankan. Edisi kelima. Jakarta. Lembaga Penerbit Fakultas Ekonomi Universitas Indonesia.

Sitompul. Zulkarnain. Pentingnya Keberadaan LPS Bagi Nasabah Penyimpan, 
Disampaikan pada Stadium General Prodi Ilmu Hukum Fakultas Syariah dan Hukum UIN Syarif Hidayatullah, Jakarta, 11 September 2014

Sugiono, 2010, Metode Penelitian Bisnis, Bandung Penerbit Alfa Beta,

Undang-Undang No. 24/2014 Tentang Lembaga Penjamin Simpanan

Undang-Undang No. 9/2016 Tentang Pencegahan dan Penanganan Krisis Sistem Keuangan

www.lps.go.id

www.bi.go.id

www.kemenkeu.go.id

www.ojk.go.id 